\title{
Mais uma vez o conceito de gestão social
}

\author{
FERNANDO GUILHERME TENÓRIO ${ }^{1}$ \\ EdgiLSON TAVARES de ARAúJo 23 \\ ${ }^{1}$ Fundação Getulio Vargas (FGV EBAPE) / Escola Brasileira de Administração Pública e de EMpresas, Rio de JaneIRo - RJ, BRASil \\ 2 UNIVERSIDAde FEDERAL dA BAHIA (UFBA) / Escola de AdMINISTRAÇÃO, SALVAdOR - BA, BRASIL \\ ${ }^{3}$ Universidade Federal do RecôncaVo da Bahia (UFRB) / Programa de Pós-graduação em Gestão de Políticas Públicas E \\ Segurança Social, CRuz dAs Almas - BA, BRASIL
}

\begin{abstract}
Resumo
Este artigo busca repetir, uma vez mais, o conceito de gestão social, que talvez seja um sonho que pode não se realizar, dadas as condições de "temperatura e pressão" sob as quais vivemos na contemporaneidade. Não obstante, a resistência conceitual deve ser o motivo para que possamos reagir ao que consideramos predominante na hodierna área da Administração: a gestão estratégica. Assim, a repetição de um tema que, desde o início dos anos 1990, vem sendo apresentado à academia brasileira é um caminhar em busca de uma qualificação melhor para o conceito central deste texto: a gestão social. Para tanto, apesar de estarmos no início do século XXI, recorremos ao fim do século XVIII, a fim de aproximar o conceito de gestão social dos parâmetros iluministas dessa centúria. Iluminismo ou barbárie? Eis a questão.
\end{abstract}

Palavras-chave: Gestão social. Gestão estratégica. Modernidade. Pós-modernidade.

\section{Reinforcing the concept of social management}

\section{Abstract}

The concept of social management may be considered unreachable, even a dream, when observing the current context. However, it is crucial to emphasize social management and resist the concept of strategic management that is predominant in today's administration area. Thus, the repetition of a theme that has been debated in Brazilian academia since the early 1990s is a journey in search of a better qualification for the central concept of this text: social management. Therefore, although we are at the beginning of the twenty-first century, it is crucial to return to the end of the eighteenth century to observe the concept of social management using the lens of enlightenment. Enlightenment or barbarism? That is the question.

Keywords: Social management. Strategic management. Modernity. Postmodernity.

\section{Una vez más, el concepto de gestión social}

\section{Resumen}

Este artículo se propone repetir y enfatizar, una vez más, el concepto de gestión social, que talvez sea una quimera, un sueño que puede no realizarse dadas las condiciones de "temperatura" y "presión" bajo las cuales vivimos en la contemporaneidad. No obstante, la resistencia conceptual debe ser el motivo que nos impulse a reaccionar a lo que consideramos predominante en la hodierna área de la Administración: la gestión estratégica. Así, la repetición de un tema que, desde el inicio de los años 1990, se está presentado a la academia brasileña es un caminar en busca de una calificación mejor para el concepto central de este texto: la gestión social. Para ello, a pesar de estar a principios del siglo XXI, recurrimos al final del siglo XVIII a los efectos de aproximar el concepto de gestión social a los parámetros iluministas de esa centuria. ¿lluminismo o barbarie? He aquí la cuestión.

Palabras clave: Gestión social. Gestión estratégica. Modernidad. Posmodernidad. 


\section{INTRODUÇÃO}

Desde o início dos anos 1990, a academia brasileira vem se deparando com o conceito de gestão social, que ora é aceito por ela, com exceções, ora é relegado. A proposição de um conceito gerencial que se contraponha àqueles do mainstream ainda carece de melhor institucionalização ${ }^{1}$ no ensino, na pesquisa e na extensão, o que ocorre principalmente nas instituições de ensino superior dedicadas à Administração (Pública e Privada) e ao Serviço Social. Essa carência se mantém mesmo com apoios institucionais como o da Coordenação de Aperfeiçoamento de Pessoal de Nível Superior (Capes), que, por meio de editais, estimula a discussão do tema e a criação da Rede de Pesquisadores em Gestão Social (RGS), e o dos Encontros Nacionais de Pesquisadores em Gestão Social (Enapegs), entre outros. A circunstância pode ser observada nos debates que circulam pela RGS e/ou em outros ambientes acadêmicos, como na Associação Nacional de Pós-Graduação em Administração (Anpad), bem como nas recentes Associação Nacional de Ensino e Pesquisa do Campo de Públicas (Anepcp) e Sociedade Brasileira de Administração Pública (SBAP), ${ }^{2}$ espaços institucionais nos quais o significado de gestão social ainda não conseguiu se impor por completo. A pretensão deste artigo é reiterar, quiçá ampliando, o que foi escrito em textos anteriores. ${ }^{3}$

Por que reiteramos? Porque defendemos que o tipo de gestão predominante em nossa sociedade de organizações, lastreada por um modo de produção que reproduz exclusão e desigualdade centrada no cálculo e na operacionalidade cega do mercado, não é capaz de atender às necessidades da sociedade. Isso ocorre porque suas práticas gerenciais atendem aos interesses estratégicos de sistemas e indivíduos e/ou grupos que alimentam e são alimentados por esses mesmos sistemas naquilo que é vantajoso - de maneira geral, o conformismo com o status quo, que na sociedade de mercado significa operar sob a prevalência da manutenção dos ganhos/lucros auferidos nas operações comerciais e/ou financeiras. Desconsidera-se, assim, a gestão como um elemento dinâmico que envolve pessoas e valores, cujo impacto se estende para além do processo de trabalho organizacional em si, implicando repercussões sociais (ARAÚJO, 2012). Portanto, de qual gestão estamos falando e à qual nos contrapomos? Aqui nos contrapomos à gestão estratégica, ${ }^{4}$ modo de administrar em que o cálculo monetário das consequências, o valor de troca, é a referência primordial no processo de tomada de decisão. A gestão estratégica remete a "um tipo de ação social utilitarista, fundada no cálculo de meios e fins e implementada mediante a interação de duas ou mais pessoas, na qual uma delas tem autoridade formal sobre a(s) outra(s)". Assim, ela prevalece nas organizações empresariais privadas, nas quais se determinam suas condições de funcionamento e o Estado a impõe à sociedade "por meio de processos eminentemente fundados na razão técnica, configurando intervenções de caráter tecnoburocrático" (GIOVANNI e NOGUEIRA, 2015, p. 412). Desde o seu nascedouro, no século XIX, a gestão estratégica é entendida e praticada de forma a-histórica, ao sabor dos modismos que, de vez em quando, surgem na literatura gerencial. Utiliza-se uma lógica "gerencialista", que é uma ideologia do poder que se vale de regras racionalistas, prescrições precisas, instrumentos de medida sofisticados, técnicas avaliativas objetivas, mas também se usam "regras irracionais, de prescrições irrealistas, de painéis de bordo inaplicáveis e de julgamentos arbitrários" (GAULEJAC, 2007, p. 37-38).

A gestão social surge, portanto, de modo antitético à gestão estratégica, buscando uma sociedade mais justa e democraticamente articulada na gestão dos seus interesses, que não os do mercado, enclave da sociedade e que deseja substituí-la como totalidade. Ou seja, sob a perspectiva de uma gestão centrada no cálculo, reiteramos a possibilidade de uma gestão no interior das organizações e entre estas e a sociedade, uma gestão social. Trata-se, portanto, da contraposição à gestão estratégica, na medida em que "tenta substituir a gestão tecnoburocrática, monológica, por um gerenciamento participativo, dialógico,

\footnotetext{
${ }^{1}$ Além de pesquisas e atividades de extensão, existem muitos cursos de graduação e pós-graduação institucionalizados, porém com diferentes enfoques, sem a definição, por exemplo, sobre o que se deve ensinar acerca de gestão social. Isso pode levar, por vezes, a certa banalização e equívocos sobre tal conceito. ${ }^{2}$ A Anepcp e a SBAP têm representado os cursos do chamado Campo de Públicas, que envolve graduações e pós-graduações em Administração Pública, Gestão Pública, Políticas Públicas, Gestão de Políticas Públicas, Gestão Social e congêneres. Muitos membros delas também fazem parte do RGS. Mais informações em www.anepcp.org.br e www.sbap.org.br

${ }^{3}$ "Gestão social: uma perspectiva conceitual", "(Re)visitando o conceito de gestão social" e "Reprisando o conceito de gestão social” poderão ser encontrados em TENÓRIO, F. G. Uma alternativa: gestão social. Ijuí: Editora Unijuí, 2016; “Escorços sobre gestão pública e gestão social” em MARTINS, P. E. M. et al. (Orgs.). Estado e gestão pública: visões do Brasil contemporâneo. Rio de Janeiro: FGV, 2006. p. 107-132; "Gestão social: uma réplica" em RIGO, A. S. et al. (Orgs.). Gestão social e políticas públicas de desenvolvimento: ações, articulações e agenda. Recife: Univasf, 2010; e "Gestão social, um conceito não idêntico? Ou a insuficiência inevitável do pensamento" em CANÇADO, A. C. et al. (Orgs.). Gestão social: aspectos teóricos e aplicações. Ijuí: Editora Unijuí, 2012. p. 23-35. ${ }^{4}$ Para Tenório (1998, p. 14), "gestão estratégica é um tipo de ação social utilitarista, fundada no cálculo de meios e fins e implementado através da interação de duas ou mais pessoas, na qual uma delas tem autoridade formal sobre a(s) outra(s). Por extensão, neste tipo de ação gerencial o sistema-empresa determina suas condições de funcionamento e o Estado se impõe sobre a sociedade. É uma combinação de competência técnica com atribuição hierárquica, o que produz a substância do comportamento tecnocrático. Por comportamento tecnocrático, entendemos toda ação social implementada sob a hegemonia do poder técnico ou tecno-burocrático, que se manifesta tanto no setor público quanto no privado, fenômeno comum as sociedades contemporâneas".
} 
no qual o processo decisório é exercido por meio dos diferentes sujeitos sociais" (TENÓRIO, 1998, p. 16). ${ }^{5}$ É um "processo gerencial dialógico no qual a autoridade decisória é compartilhada entre os participantes da ação (ação que possa ocorrer em qualquer tipo de sistema social - público, privado ou de organizações não governamentais)" (TENÓRIO, 2008, p. 39). É com base nesse conceito seminal, um dos mais citados na literatura sobre o tema, que tem como premissa analítica o agir comunicativo ${ }^{6}$ e a democracia deliberativa de Jürgen Habermas, que são inspiradas outras conceituações e proposições de e sobre gestão social. Atualmente, há múltiplos conceitos e uma polissemia sobre a gestão social (ARAújO, 2012). ${ }^{7}$ Há similaridades e distinções entre os que afirmam e defendem o que é e não é gestão social, prevalecendo em todos a noção de que esta é dialógica e participativa; voltada a mudança e inovação dos padrões vigentes; promotora do desenvolvimento socioterritorial, do fortalecimento da democracia, da consolidação da cidadania e da governança, como os principais valores ideológicos e elementos estruturantes que os regem (ARAÚJO, 2012).

Por que insistimos em manter na pauta acadêmica o conceito de gestão social? Possivelmente são dois os motivos. Um deles está relacionado ao esgotamento de um modelo de organização política e econômica que, sob a óptica da sociedade submetida aos cânones do mercado, não dá conta das necessidades republicanas, do bem comum dessa mesma sociedade, uma vez que a concentração da renda nacional, aqui e alhures, sob o controle de poucos, impede que a maioria da população usufrua os resultados da produção nacional. Por sua vez, o processo político de tomada de decisão está submetido a uma representatividade, em seus diferentes níveis, na qual os eleitos pela população só atendem aos interesses daqueles que potencializam financeiramente sua eleição. Assim, a sociedade não tem o controle desses processos e de outros que a acometem gerencialmente. Por que a sociedade é gerencialmente acometida, agredida? Porque o estamento tecnoburocrático, público ou privado, não é capacitado e cria valores sociais para entender e atender ao interesse geral da cidadania e/ou da coisa pública. O estamento é treinado para atender, quando muito, ao formalismo burocrático e/ou técnico - ou, quase sempre, ao interesse privado. No caso da Administração e de outras áreas, como a Engenharia de Produção, a normatização e o lucro têm sido a referência curricular dessas habilitações.

Mais uma vez, cito que a intenção deste texto é voltar a apresentar o que já foi dito em outras ocasiões, com o intuito de valorizar o conceito de gestão social, cujo significado procura ser antitético ao de gestão estratégica, que sequer se permite ser questionado, dada sua arrogância. Na gestão social, "a verdade só existe se todos os participantes da ação admitem sua validade, isto é, a verdade é a promessa de consenso racional, não é uma relação entre o indivíduo e sua percepção de mundo, mas sim um acordo alcançado por meio da crítica intersubjetiva" (GIOVANNI e NOGUEIRA, 2015, p. 412).

Assim, o que pretendemos? Manter em ensaio, sem a possibilidade de ser definitivo, um conceito gerencial mais próximo do significado republicano de res publica do que aquele gerencial que apenas exclui, sem acrescentar ou incorporar.

Leitores e leitoras observarão que este pretenso conjunto de palavras aqui exposto carece de conteúdo lavrado somente na administração, isto é, o texto não foi delineado com base nos conteúdos originados em tal ciência social aplicada. O conhecimento produzido nessa área não dá conta do complexo contexto ao qual ela deveria se submeter, ou seja, à sociedade. Daí a necessidade de a leitura dos fenômenos gerenciais e/ou organizacionais ser subordinada a uma compreensão crítica de tais fenômenos, sob o risco de mistificar uma área de conhecimento aquém do seu potencial, que é originalmente o mercado. Por outro lado, devemos considerar que, apesar de o texto procurar fundamentar sua redação com argumentos da filosofia e/ou da teoria social, não tem a pretensão de enunciar nem um nem outro desses saberes. 0 intento foi apenas o de percorrer a aprendizagem por meio de saberes que de melhor maneira expliquem os fenômenos organizacionais, predominantemente auxiliares das nefastas contradições da sociedade centrada no mercado.

\footnotetext{
${ }^{5}$ Cançado (2011), Araújo (2012), Coelho e Menon (2019), Aguiar-Barbosa e Chim-Miki (2020) apontam que nesse artigo publicado por Tenório (1988) na RAP provavelmente temos o primeiro texto nacional a tratar conceitualmente do termo, sendo fundante de uma primeira geração da gestão social.

${ }^{6}$ Aqui não cabe descrever a teoria social habermasiana; apenas destacamos duas das cinco ações sociais proferidas por Habermas - estratégica e comunicativa -, que permitiram a criação dos conceitos de gestão estratégica e gestão social por Tenório (1998). Ação estratégica: "Quando no cálculo que o ator faz de seu êxito intervêm a expectativa de decisões de ao menos outro ator que também atua com vistas à realização de seus próprios propósitos. Esse modelo de ação é interpretado de forma estritamente utilitarista; então se supõe que o ator eleja e calcule meios e fins desde o ponto de vista da maximização da utilidade ou expectativa de utilidade" (HABERMAS, 1987, p. 123). Ação comunicativa: "Refere-se à interação de ao menos dois sujeitos capazes de linguagem e de ação que (já seja com meios verbais ou com meios extra verbais) entabulam uma relação interpessoal. Os atores buscam entender-se sobre uma situação de ação para poder assim coordenar de comum acordo seus planos de ação e com ele suas ações. O conceito aqui central é o de interpretação, [que] se refere primordialmente à negociação de definições da situação susceptível de consenso" (HABERMAS, 1987, p. 124)

${ }^{7}$ Ver Araújo (2012, p. 72), que propõe um quadro analítico comparativo sobre conceitos e concepções de gestão social traçados por Singer (1999), Dowbor (1999), Carvalho (1999), Fischer (2002, 2009), Filho (2003, 2008), Maia (2005a, 2005b), Boullosa e Schommer (2008, 2009). Ver também Cançado (2011).
} 
À semelhança de outras disciplinas de cariz funcionalista, a administração parece estar mais próxima de processos de subordinação do que daqueles saberes que procuram promover a emancipação humana. Portanto, o texto aqui desenvolvido procura dar conta de uma necessidade imperiosa: focar seu conteúdo na questão social e em suas expressões, ${ }^{8}$ isto é, no bem-estar geral, e não exclusivamente na questão econômica, ou seja, no bem-estar material. Social aqui será entendido não só como um adjetivo, mas de modo substantivo, como pertencente a "um espaço público de inter-relações" (ARAúJO, 2012) ou "à sociedade, ou [que] diz respeito à sociedade enquanto tal, isto é, aos fenômenos e às relações sociais que a constituem" (LALANDE, 1996, p. 1041). Desse modo, as organizações e a maneira como elas promovem e gerenciam suas relações sociais, interna e externamente, tendem a desencadear a dinâmica das sociedades. Portanto, discutir o social é fazê-lo sob um viés na qual o conhecimento do seu significado não é privilégio de nenhum saber em particular, mas de todos aqueles saberes que tratam de relações e questão social e suas mutações. Ou seja, demanda saberes, epistemes e ontologias, não assentado numa lógica da colonialidade na qual o poder do conhecimento age de forma a manter a hegemonia eurocêntrica como perspectiva superior (QUIJANO, 2005). A gestão social traz uma possibilidade de decolonialidade epistemomológica e ontológica, que, de modo interdisciplinar, busca uma radical humanização da gestão numa óptica dialógica, a fim de que possa ser mais libertadora, e não opressora. Além disso, os conceitos de gestão social são propostos por teóricos latino-americanos, sobretudo brasileiros (ARAÚJO, 2012), que os anunciam com base em práticas teorizadas de modo significado num contexto de lutas sociais ${ }^{9}$ por mudanças políticas, econômicas e ambientais, promovidas por múltiplos atores sociais mobilizados em diferentes formas (inter)organizacionais, em torno de novos modos e finalidades para a gestão.

O conteúdo aqui explorado é constituído de interpretações, inclusive de contínuo autoesclarecimento, das decifrações que os autores fazem de um tema cuja novidade ou resistência está em processo. No entanto, isso não significa dizer que as posições antes assumidas, no início desse debate nos anos 1990, tenham sido alteradas. Pelo contrário, nossa posição, e a de outros que acompanham essa atitude, é que o significado de gestão social aqui pretendido é aquele contraposto ao de gestão estratégica. Assim, algumas questões fazem parte dessa interpretação. Até que ponto é possível discutir significados de gestão sem se apegar aos parâmetros universais da racionalidade instrumental? Até que ponto é concebível debater e praticar processos gerenciais não submetidos ao cálculo do mercado? Até que ponto é admissível, num mundo dominado pelo valor de troca, apontar caminhos fundamentados no valor de uso? Até que ponto é possível uma gestão deliberativa, em vez da gerência delegada? O presente texto não pretende dar as respostas; apenas induzi-las. Para tanto, focalizaremos a discussão sob os parâmetros projetados pela modernidade.

Além desta Introdução e do referencial bibliográfico, o texto foi dividido em mais três itens na seguinte sequência: "Modernidade", "Iluminismo ou barbárie" e "Considerações finais: gestão social ou gestão estratégica".

\section{MODERNIDADE}

O estímulo para reprisar o conceito de gestão social será desenvolvido a partir de dois períodos da história: a modernidade - superada para alguns, daí o advento do conceito de "pós-modernidade", enquanto para outros ainda é um projeto da humanidade - e a hipermodernidade. A modernidade diz respeito a uma "nova forma de pensamento e de visão de mundo inaugurada pelo Renascimento e contrapondo-se à escolástica e ao espírito medieval, desenvolvendo-se nos séculos XVI e XVII com Francis Bacon, Galileu e Descartes, dentre outros, até o lluminismo, do qual é a principal expressão" (JAPIASSU e MARCONDES, 1990, p. 170). Lyotard apresenta a ideia de "condição pós-moderna" como a necessidade de uma "superação da modernidade, sobretudo da crença na ciência e na razão emancipadora, considerando que estas são, ao contrário, responsáveis pela continuação da subjugação do indivíduo". Habermas defende o "projeto de modernidade", uma vez que este "não está acabado, mas precisa ser levado adiante, e só através dele, pela valorização da razão crítica, será possível obter

\footnotetext{
${ }^{8}$ A questão social diz respeito aos efeitos do sistema capitalista de produção gerando as relações capital-trabalho e a luta de classes sociais. Tal categoria analítica foi ganhando novos contornos difusos graças aos elementos histórico-culturais e às mudanças nas relações no mundo do trabalho e nos processos produtivos; às relações entre Estado e sociedade; às políticas sociais, principalmente o chamado "princípio da exclusão", que, de modo ambíguo, remete ao tema indígena, racial e de gênero (WANDERLEY, 2008). "A questão social passa, portanto, a se configurar como a luta contra as expressões da desigualdade, pobreza e exclusão social. Essas expressões são enfrentadas neste terceiro milênio desde a caridade renovada e pela filantropia empresarial, até ações de diferentes roupagens criadas pelo capitalismo para o fortalecimento do capital, ao invés dos sujeitos" (ARAÚJO, 2012, p. 59).

9 "As lutas sociais também são cenários pedagógicos nos quais os participantes exercem suas pedagogias de aprendizagem, desaprendizgem, reaprendizagem, reflexão e ação" (WALSH, 2013, p. 29 - tradução livre).
} 
a emancipação do homem da ideologia e da dominação política e econômica" (HABERMAS, 1987). O trabalho de Gaulejac (2007, p. 33) aponta que a hipermodernidade é um termo proposto inicialmente por Max Pagès, em 1979, e posteriormente aprofundado por Nicole Aubert, em 2004, e por Gilles Lipovetsky, de modo a descrever "a exacerbação das contrariedades da modernidade". Isso envolve a "dominação 'irracional' da racionalidade instrumental, a realização de progressos tecnológicos e econômicos que são fatores de regressões sociais, a conquista de autonomia dos indivíduos, que os põe em dependência".

De imediato, advertimos que a posição assumida neste artigo acompanha a vertente de que a modernidade ainda está por ser alcançada. Desse modo, defendemos que conceitos e práticas gerenciais não atendem ao projeto da modernidade, quiçá apenas da modernidade capitalista. ${ }^{10}$ Por sua vez, o conceito e a prática gerencial que requeremos devem ser similares aos postulados do lluminismo, momento convergente na história da filosofia com a modernidade que corresponde ao surgimento de uma inflexão, possibilitando ao homem ter a própria luz por meio da razão, ${ }^{11}$ substantivo que distingue os homens dos animais na medida em que possibilita ao ser humano raciocinar, compreender e julgar, eticamente, sua relação com a natureza e com outros homens, atuando como um ser social. A razão é a capacidade humana que pode levar a práticas gerenciais e operacionais que alcancem o bem comum, ${ }^{12}$ eixo central de uma gestão compartilhada, como seria o caso da gestão social. Desse modo, entender a importância da modernidade, do lluminismo (Ilustração, Filosofia das Luzes, Esclarecimento, Séculos das Luzes), é condição sine qua non para a compreensão de um significado que pretende ser um modo gerencial que o diferencie do predominante, do hegemônico, da gestão estratégica.

Portanto, o significado de Iluminismo, aqui descrito como referência ao conceito de gestão social, acompanha Sérgio Paulo Rouanet, quando, em Mal-estar na modernidade, conceitua lluminismo como "um ens rationis, ${ }^{13}$ um éthos, uma ideia, não uma época ou um movimento [como a] Ilustração, [...] um momento na história cultural do ocidente. Enquanto construção, o lluminismo tem uma existência meramente conceitual: é a destilação teórica da corrente de ideias que floresceu no século XVIII" (ROUANET, 1993, p. 13). É esse engendramento, de um projeto ainda não concluído na história da humanidade, que gostaríamos que fosse referência a um modo gerencial (gestão social) equidistante daquele (gestão estratégica) que produz alienação, conformismo, consumismo, particularismo, produtivismo, enfim, letargia. A seguir, procuraremos ampliar a discussão do significado do éthos da modernidade.

Os conceitos de modernidade e pós-modernidade têm sido transversais ao pensamento ocidental, tanto no que diz respeito a estudos de temas relacionados à estética quanto nos debates envolvendo as ciências sociais. Tais alusões, em alguns casos, passam a ser utilizadas por puro modismo, pois muitas vezes as pronunciamos sem saber ao certo do que falamos. Esses conceitos são apresentados como contraditórios, em especial porque pós-modernidade se distingue de modernidade pelo fato de o prefixo "pós" (após) atribuir conteúdo antitético à modernidade, uma vez que este, modernidade, teria envelhecido, seria passado. Ainda não há, porém, consenso quanto a isso, considerando as posições de Jean-François Lyotard e Jürgen Habermas. O primeiro defende a existência da pós-modernidade, ao passo que o segundo sustenta que a modernidade persiste como projeto. Há ainda aqueles que consideram a pós-modernidade um modismo, uma abundância de conceitos que surgem a cada dia, e que nós, do mundo acadêmico, devemos conhecê-los para estar in, e não out.

\footnotetext{
10 "[A] modernidade capitalista é cumulativa [...] é ao mesmo tempo global e desigual - produto de um mesmo processo que se expressa de formas diversas em lugares diferentes" (MENDONÇA, 2014, p. 62-63).

${ }^{11}$ Razão: "1. Faculdade de julgar que caracteriza o ser humano. A capacidade de bem julgar e distinguir o verdadeiro do falso, [...]. 2. Em sentido mais específico, a razão é a capacidade de, partindo de certos princípios a priori, isto é, estabelecidos independentemente da experiência, estabelecer determinadas relações constantes entre coisas, permitindo assim chegar à verdade, ou demonstrar, justificar uma hipótese ou uma afirmação qualquer. Nesse sentido, a razão é discursiva, ou seja, articula conceitos e proposições para deles extrair conclusões de acordo com princípios lógicos. 3. A razão identifica-se ainda com a luz natural, ou o conhecimento de que o homem é capaz naturalmente, por oposição à fé e à revelação" (JAPIASSU e MARCONDES, 1990, p. 209). "Na linguagem corrente, razão é sinônimo de entendimento. De fato, ela não dá um passo sem o entendimento, mas o supera. [...] está em movimento [...]. Deseja a reflexão; opõe-se à arbitrariedade. Realiza o autoconhecimento de cada um e, ao conhecer as limitações, a humildade pessoal; opõe-se a arrogância. [...]a razão não existe por natureza, mas realmente apenas por decisão. Não acontece por si mesma, como um fato natural e como a totalidade da existência humana concreta, na medida em que esta tem caráter de natureza, mas nasce da liberdade" (JASPERS, 1958, p. 49-57).

${ }^{12}$ Para Matteucci (2010, p. 106-107), a ideia de bem comum é originário do pensamento político católico, principalmente com Tomás de Aquino e Maritain, tendo como base o solidarismo. Distingue-se do bem individual e do bem público. "Enquanto o bem público é o bem de todos por estarem unidos, o bem comum é dos indivíduos por serem membros de um Estado. trata-se de um valor comum que os indivíduos podem perseguir somente em conjunto, na concórdia." Por isso, apresenta analogias com a "vontade geral" e tem relação com a análise econômica dos bens coletivos ou públicos, com as concepções do necontratualismo. Trata-se de uma categoria que explicita a tentativa de maior integração social por meio do consenso.

${ }^{13}$ Ens rationis seria um "objeto de pensamento artificialmente criado pelo espírito para as necessidades do discurso e sem existência em si, nem na representação concreta. Neste sentido, todas as ideias abstratas e gerais foram algumas vezes chamadas 'entes de razão'; mas este termo emprega-se, sobretudo, no sentido pejorativo, para insistir sobre o caráter verbal ou irreal daquilo que assim é chamado” (LALANDE, 1996, p. 304-305). Apesar do sentido depreciativo que um pensamento abstrato possa adquirir, aqui não o utilizaremos dessa forma. Em simultâneo a ens rationis, empregaremos éthos, ideia, para significar valores que influenciem o conceito de gestão social.
} 
O que está por trás dessa questão, para Rouanet, é bobagem pura e simples, já que há no Brasil um familiaríssimo festival de besteiras, "que parece ter a tendência de ressurgir ciclicamente em determinados períodos da nossa história, com o agravante, no caso, de que se trata de um bestialógico importado. [...] De alguma forma, as pessoas acham que a modernidade envelheceu. O moderno ficou fora de moda" (ROUANET, 1986, p. 87).

De acordo com Zygmunt Bauman e Carlos Bordoni, comentando o pensamento de François Lyotard, a modernidade não teria envelhecido porque a pós-modernidade é um momento da modernidade. Assim, a pós-modernidade "foi o momento de aprender quais das promessas da modernidade eram fraudulentas ou ingênuas pretensões, quais de suas ambições eram manifestações de arrogância condenável e quais de suas intenções latentes foram encobertas por objetivos tão somente proclamados" (BAUMAN e BORDONI, 2016, p. 105-106).

Para a socióloga e feminista Maria Lugones, "a modernidade organiza o mundo ontologicamente em termos de categorias homogêneas, atômicas, separáveis" (LUGONES, 2014, p. 935). Haveria, assim, uma primeira modernidade, a colonial, que se refere ao momento da conquista dos colonizadores, e uma segunda, a capitalista, surgida com a Revolução Industrial. A colonização das Américas e do Caribe impõe a hierarquia dicotômica entre o humano e o não humano, bem como entre homens e mulheres, civilizados e não civilizados. ${ }^{14}$ "O homem europeu, burguês, colonial moderno tornou-se um sujeito/agente, apto a decidir, para a vida pública e o governo, um ser de civilização, heterossexual, cristão, um ser de mente e Razão" (LUGONES, 2014, p. 936). Assim, Dussel aponta a América Latina como a primeira colônia europeia, e África e Ásia, como as primeiras "periferias":

A colonização da vida cotidiana do índio, do escravo africano pouco depois, foi o primeiro processo "europeu" de 'modernização', de civilização, de "subsumir" (ou alienar) o Outro como "si-mesmo"; mas agora não mais como objeto de uma práxis guerreira, de violência pura - como no caso de Cortês contra os exércitos astecas, ou de Pizarro contra os incas -, e sim de uma práxis erótica, pedagógica, cultural, política, econômica, quer dizer, do domínio dos corpos pela machismo sexual, da cultura, de tipos de trabalhos, de instituições criadas por uma nova burocracia política etc., dominação do outro. É o começo da domesticação (DUSSEL, 1993, p. 50).

Svampa (2016, p. 17-18) aponta que haveria três correntes de pensamento. A primeira trabalha sob a perspectiva da "subalternidade" ou do "pós-colonialismo", que "questionou os paradigmas nacional ou nacionalista e marxista, assim como enfocou a necessidade de pensar o subalterno como tal, como algo irredutível cuja voz não podemos nos apropriar nem conhecer em sua totalidade, em um marco no qual, ademais, as identidades são sempre migrantes e cambiantes". A segunda, a "decolonial", procura fazer uma interpretação epistêmica de nossa "insuficiência" e aponta a necessidade de conhecermos pensadores clássicos e contemporâneos da América Latina, para melhor entender e ampliar a leitura de abya yala. Aqui identificaremos, por ordem alfabética, alguns desses pensadores: Alberto Guerreiro Ramos, Aníbal Quijano, Bolívar Echeverría, Catherine Walsh, ${ }^{15}$ Darcy Ribeiro, Enrique Dussel, José Carlos Mariátegui, José Martí e Walter Mignolo. Essa perspectiva inicialmente desenvolvida por Quijano, por meio da categoria "colonialidade do poder", depois denominada por Edgardo Lander de "colonialidade do saber", enfatiza que as ciências sociais naturalizaram os conceitos e as categorias das ciências sociais que se apregoaram com a expansão do colonialismo. Além disso,

esta naturalização das diferentes dimensões da modernidade tem como piso a derrota de nossas culturas tradicionais e das culturas populares ou plebeias e o triunfo de uma nova realidade (capitalista), que organizou o tempo e os territórios da maneira diferente. [...] e, portanto, também, a naturalização da superioridade de alguns saberes sobre outros. Este processo de naturalização foi acentuado com a profissionalização das ciências sociais (SVAMPA, 2016, p. 18-19).

\footnotetext{
14 "Só os civilizados são homens ou mulheres. Os povos indígenas das Américas e os/as africanos/as escravizados/as eram classificados/as como espécies não humanas - como animais, incontrolavelmente sexuais e selvagens (LUGONES, 2014, p. 936).

${ }^{15}$ Walsh apresenta a ideia de decolonialidade e pedagogia decolonial, com referências no projeto de modernidade/colonialidade, que, a partir de 2004 abre uma nova fase de reflexão e discussão. Ela retira propositalmente o "s" do termo descolonial e descolonizador de Fanon (2008), autor que faz análise do racismo, inclusive epistemológico, como algo socialmente gerado pelos colonizadores europeus na perspectiva de racialização e desumanização. Walsh, assim, classifica decolonialidade, pelo viés de Paulo Freire, como a ideia de pedagogia libertadora. "O decolonial denota, então, um camino de luta contínua no qual se pode identificar, viabilizar e encorajar 'lugares' de exterioridade e construções de alter-(n)ativas” (WALSH, 2013, p. 25 - tradução livre).
} 
A terceira linha de pensamento apontada por Svampa (2016) seria aquela desenvolvida por Boaventura de Sousa Santos, denominada "epistemologias do sul", que "aponta a busca de conhecimento e de critérios de validez do conhecimento que outorguem visibilidade e credibilidade as práticas cognitivas das classes, dos povos e dos grupos sociais que têm sido historicamente vitimados, explorados e oprimidos pelo colonialismo e pelo capitalismo" (SANTOS apud SVAMPA, 2016, p. 19). ${ }^{16}$

A análise de Quijano fornece uma compreensão histórica "da inseparabilidade da racialização e da exploração capitalista como constitutiva do sistema de poder capitalista que se ancorou na colonização das Américas" (LUGONES, 2014, p. 939). Assim, a colonialidade implica discriminações raciais, exploração e formas de controle do trabalho (escravidão, servidão), eurocentrismo dominando as subjetividades e um sistema de controle da autoridade coletiva em torno da hegemonia do Estado-nação (QUIJANO, 1991, 1995; QUIJANO e WALLERSTEIN apud LUGONES, 2014). A ideologia da gestão estratégica associada à lógica modernidade/colonialidade, como trazida pela administração, acaba reforçando tais implicações. A gestão social, ao contrário, vem de encontro ao conformismo do status quo trazido pela sociedade de mercado, que opera sob a prevalência do capital sobre o trabalho, ou uma condição necessária e mesmo vital em todos os tipos de organizações (ARAÚJO, 2012), desconsiderando valores e diversidades das pessoas.

Essas discordâncias trazidas por diferentes autores(as) com relação à modernidade podem estar assentadas na seguinte pergunta: a inexorabilidade da modernidade continua nos dias de hoje ou o contemporâneo já é inspirado por outra categoria paradigmática? Se considerarmos que o termo "moderno" já existia "desde o século V da era cristã", ou se consultarmos dicionários da língua portuguesa, encontraremos que "moderno" identifica a época na qual uma pessoa vive e que a modernidade é a qualidade do que é moderno (JAMENSON, 2005, p. 27). Assim, por que discutir seu oposto, a "pós-modernidade", se a modernidade está sempre em processo? Por que reafirmar e avançar com o conceito de gestão social como construto decolonial, em contraponto à lógica moderna colonizadora e capitalista da gestão estratégica?

Apesar disso, como já adiantado, a modernidade pode ser estudada como uma categoria na história da filosofia ocidental. Significaria uma época iniciada a partir da ruptura epistemológica com um passado em que o homem não tinha o direito de pensar, refletir sobre sua condição de um ser para si. Seu cogito era subsumido por um pensar já dado, um saber originado numa luz que vinha do cimo, dos céus. O homem não poderia ter a própria luz, o próprio esclarecimento; a consciência não se fazia por meio da experiência, da reflexão, mas do divino, do absoluto ou daqueles que intermediavam o celestial com os mortais. ${ }^{17}$ Com a modernidade, o secularismo, o mundano, se fez presente, a razão começou a se impor. Portanto, a "modernidade substitui Deus no centro da sociedade pela ciência, deixando as crenças religiosas para a vida privada" (TOURAINE, 1994, p. 18). Racionalidades começaram, então, a ser produzidas, e os conceitos "razão" e "racionalidade"18 se tornaram fundamentais para as ciências sociais em função do surgimento dos saberes especializados, que, entre outros fatores, passaram a representar uma ruptura no conhecimento do homem e de suas ações diante dos outros e da natureza.

Essa ruptura toma como referência a substituição da epistemologia de base escolástica ${ }^{19}$ por outra para a qual converge o pensamento de autores como Francis Bacon (1561-1626), Hugo Grócio (1583-1645), Thomas Hobbes (1588-1679), René Descartes (1596-1650) e John Locke (1632-1704), que consideram que toda certeza, toda verdade, deveria ser submetida a uma análise racional. A modernidade surge com o propósito de libertar os indivíduos das crenças religiosas e criar, assim, o homem moderno. A modernidade, porém, segue seu propósito ilustrativo, esclarecedor, iluminando o século XVIII por meio da filosofia de Voltaire/ François Marie Arouet (1694-1778), Jean-Jacques Rousseau (1712-1778), Denis Diderot (1713-1784), Barão d’Holbach (1723-1789), Immanuel Kant (1724-1804), Marquês de Condorcet/Marie Jean Antoine Nicolas de Caritat (1743-1794), bem como da Revolução Francesa (1789) e de suas consequências. Assim, os "termos Ilustração [esclarecimento -

\footnotetext{
${ }^{16}$ O livro em referência é: SANTOS, B. S. Refundación del Estado en América Latina: perspectivas desde una epistemología del sur. Quito: Ediciones Abya-Yala, 2010. 17 "O início do século XVII marca a verdadeira entrada na modernidade [...] [seu] caráter efêmero favorece o aumento do ceticismo. O processo é lento de início, e atinge apenas uma elite do pensamento, porém, uma vez lançado, nada o detém. Da quase unanimidade da fé medieval à extrema dispersão das crenças atuais, assiste-se a uma espécie de entropia do pensamento religioso" (MINOIS, 2014, p. 211).

${ }^{18}$ Racionalidade: "1. [...] A racionalidade é a característica daquilo que é racional, que está de acordo com a razão. [...] 3. Max Weber (A ética protestante e o espírito do capitalismo, 1904) distingue a ação racional valorativa (Wertrational) da ação racional instrumental (Zweckrational). A primeira caracteriza uma ação que se realiza de acordo com certos valores e que se autojustifica, como p. ex. os rituais em certas culturas. A segunda caracteriza como racional uma ação ou procedimento que visa fins ou objetivos específicos, procurando realizá-los através de cálculos e da adequação dos meios a estes fins; dessa forma, os fins justificariam os meios mais eficazes para sua obtenção. Weber identifica a razão instrumental com o capitalismo e o desenvolvimento da técnica e da sociedade industrial" (JAPIASSU e MARCONDES, 1990, p. 208).

19 "A escolástica caracteriza-se principalmente pela tentativa de conciliar os dogmas da fé cristã e as verdades reveladas pelas Sagradas Escrituras com as doutrinas filosóficas clássicas, destacando-se o platonismo e o aristotelismo", e se desenvolveu entre os séculos IX e XVII (JAPIASSU e MARCONDES, 1990, p. 84).
} 
Aufklärung], Revolução Francesa e Modernidade constituem uma trinca com as características sedutoras de um sequência cronológica": primeiro com "a pregação ilustrada", segundo com a "realização revolucionária" e terceiro com o "mundo moderno" (ROUANET, 1993, p. 140), ou, quem sabe, de uma quatrinca, por meio da "filosofia clandestina". ${ }^{20}$ No caso da administração, a modernidade, pelo seu substantivo "modernização", promove a racionalização do processo produtivo pela incorporação da ciência e da técnica cuja exacerbação promove a gestão estratégica, contrariando pressupostos da modernidade, como a emancipação do homem.

Por sua vez, a pós-modernidade seria uma categoria formulada nas primeiras décadas do século XX, significando uma mudança no pensamento estético, e não uma categoria de determinado período. A partir dos anos 1970, no entanto, o conceito passa a ser disseminado como característica de uma época variada, múltipla, determinada pelas diferenças. $O$ texto de concepção filosófica que vai procurar romper as metanarrativas modernas da dualidade de classes ou o todo sistêmico é $A$ condição pós-moderna, de Jean-François Lyotard, obra em que, "simplificando ao extremo, considera-se 'pós-moderna' a incredulidade em relação aos meta-relatos" 21 (LYOTARD, 2006, p. XVI). No livro, o autor afirma que o "saber pós-moderno [...] aguça a nossa sensibilidade para as diferenças" (LYOTARD, 2006, p. XVII), ou a "tendência para o contrato temporário em todas as áreas da existência humana: a ocupacional, a emocional, a sexual, a política - laços mais econômicos, flexíveis e criativos que os da modernidade" (ANDERSON, 1999, p. 33). Desse modo, a pós-modernidade configuraria uma ruptura com um passado que tinha na razão o meio de o indivíduo alcançar, intelectualmente, a maioridade, a independência em relação àqueles ou às instituições que o submetiam. Também é usado para caracterizar sociedades consideradas desenvolvidas e posições desaprovadoras quanto ao uso de grandes narrativas e filosofias metafísicas (ARAÚJO, 2012).

As bases sobre as quais esse rompimento ocorre, no entanto, são as mesmas que surgem com o advento do capitalismo, sob o qual o valor de troca, a compra da força de trabalho, fundamentos desse movimento econômico, mantêm a relação de dependência, de subordinação, do assalariado ao agente comprador do potencial humano. Portanto, a modernidade não se fez, e a ela se acrescenta o prefixo "pós" para significar que vivemos mudanças, rupturas, mas, na realidade, são meras insinuações. "Não existe ruptura social, porque continuamos, ao que me consta, vivendo num sistema capitalista [...] mas com todas as suas metamorfoses, os sistemas continuam, hoje como ontem, baseando-se na estratificação social e na apropriação privada do excedente" (ROUANET, 1986, p. 88). Ou, como nos diz Habermas (2015, p. 37), “[com] esse 'pós' os protagonistas querem se distanciar de um passado (...), gestos [apressados] de despedida". Embora no mundo do trabalho, das organizações, com a incorporação de novas tecnologias, notadamente as da informação, mudanças funcionais tenham se tornado realidade, o fenômeno ocorre pelo processo da modernização, da atualização técnica, não da modernidade.

A flexibilização organizacional e do trabalho caracterizaria uma gestão pós-moderna ou, como desejam alguns, pós-fordista ou pós-industrial, pois as organizações passam a atuar pela diferenciação integrada da organização da produção e do trabalho sob a trajetória de inovações tecnológicas e mudanças na concepção jurídica do emprego, a qual contraria a fordista, uma vez que esta se baseia na previsão de um mercado em crescimento, o que justificaria o uso de equipamentos especializados para obter economia de escala, produção em massa e garantia do emprego. Agora surgem tecnologias e/ou equipamentos flexíveis, cuja finalidade é atender a demandas diferenciadas, tanto em quantidade quanto em composição de produtos ou serviços, assim como surgem novas formas de regulamentar a força de trabalho que, no fundo, procuram desregulamentar as garantias legais dessa mesma força. Porém, o modo como a organização da sociedade é economicamente gerenciada está subordinado ao viés do mercado, no qual o cálculo para explorar as condições favoráveis, portanto o lucro, alimenta a sobrevivência mercantil - ou de resultados, como preferem alguns. ${ }^{22}$

\footnotetext{
20 “[...] 'filosofia clandestina' constitui sem dúvida nenhuma, uma das mais fascinantes páginas da história do pensamento e das ideias. O que se entende por isso é um amplo 'movimento' filosófico-literário, cuja marca foi a circulação (em geral secreta e anônima) de centenas de obras anticlericais e de crítica política no período compreendido entre os séculos XVI e XVIII. Tais obras (impressas e manuscritas) refletiam a necessidade comum de expressar ideias pouco ortodoxas numa sociedade ainda refém da religião. Afinal, é preciso lembrar que a Inquisição ainda queimava seus 'hereges' e 'ímpios' em pleno século do Iluminismo e da Revolução Francesa" (MARSAIS, 2008, p. 9). Sob o escopo da filosofia clandestina, encontraremos o denominado Iluminismo radical, cujo "lema principal é: todas as pessoas possuem as mesmas necessidades básicas, direitos e status, independentemente de crença, grupo religioso, econômico ou étnico a que pertençam; e, portanto, todos devem ser tratados da mesma forma com base na isonomia, sendo eles negros ou bancos, homens ou mulheres, religiosos ou não e que todos merecem ter os seus interesses e aspirações pessoais igualmente respeitados pela lei e pelo governo" (ISRAEL, 2013).

21 “Metanarrativas são filosofias da história que narram modelos explicativos universais e estáveis, ou seja, são 'metassaberes' que estabelecem a perspectiva de conhecer a realidade e poder realizar um mundo mais justo; poder, através do conhecimento, emancipar o homem, trazer-lhe a luz, salvá-lo do obscurantismo, da selvageria, da alienação" (SILVA, 2012).

22 "O sistema de poder que se esconde nas modernas formas de flexibilidade consiste em três elementos: reinvenção descontínua de instituições; especialização flexível de produção; e concentração de poder sem centralização. Os fatos que se encaixam em cada uma dessas categorias são conhecidos da maioria de nós, nenhum mistério; já avaliar a consequência deles, é difícil” (SENNETT, 1999, p. 54).
} 
Assim, a modernização empreendida carece de modernidade, uma vez que a razão, exigida desde o lluminismo, ainda não se fez presente. Racionalidades desde então aconteceram; criaram-se novas perspectivas, e a inexorabilidade do avanço científico-tecnológico contribuiu para tanto, como é o caso das tecnologias de base microeletrônica e/ou da informação, que, sem dúvida, como o dito popular, "encurtaram distâncias" e favoreceram a aproximação, ainda que virtual, entre as pessoas. Avanços significativos nos setores primários, secundários e terciários da economia são fatos incontestáveis. Áreas como a saúde, hoje, são dependentes desses avanços tecnológicos. Benefícios tecnológicos, como a informática, favorecem a educação. Poderíamos elencar outros fatores promovidos pelas racionalidades técnico-científicas contemporâneas, sobretudo aquelas originadas nas tecnologias da informação, mas ficamos por aqui, pois o leitor é capaz de imaginá-las. No entanto, pelo fato de a razão na sua origem ser crítica, preocupada com a emancipação do homem, com potencial para apontar as contradições que se apresentam, como praticar a razão no cotidiano das organizações, cujo leitmotiv recorrente nos processos de tomada de decisão, estatal ou privado, procuram, por meio de racionalidades, produzir resultados e/ou lucros não focados no bem-estar geral? Talvez a resposta possa estar em pensar ou buscar outra forma de administrar que não aquelas mantenedoras da relação senhor-escravo - relação explicitada por Hegel na Fenomenologia do espírito (2011), cuja metáfora significa uma situação-limite que poderemos perceber por meio das hierarquias e de certas atitudes dentro e entre os sistemas sociais formalmente organizados, assim como em certas relações sociais.

\section{ILUMINISMO OU BARBÁRIE?}

Se recuperarmos as três expressões que referenciaram a Revolução Francesa em 1789 e que servem de fundamento à modernidade como movimento de busca pela emancipação humana - liberdade, igualdade e solidariedade -, até agora, início do século XXI, parece, com exceção talvez da solidariedade, que não foi possível perceber as práticas de tais fundamentos.

A liberdade diz respeito à ausência de qualquer tipo de discriminação ou marginalização da pessoa humana. Assim, "devem existir condições nas quais os indivíduos possam efetivamente exercer sua liberdade a fim de alcançarem o grau máximo de autorrealização e autocomando de que forem capazes" (BOTTOMORE e OUTHWAITE, 1996, p. 424). A igualdade prevê que toda pessoa tem o direito a ser considerada igual aos demais, não devendo ser objeto de nenhum tipo de discriminação. Implícito a essa concepção está o significado de igualdade social, ou seja, "a ideia de que as pessoas devem ser tratadas como iguais em todas as esferas institucionais que afetam suas oportunidades de vida: na educação, no trabalho, nas oportunidades de consumo, no acesso aos serviços sociais, nas relações domésticas e assim por diante" (BOTTOMORE e OUTHWAITE, 1996, p. 373). A solidariedade é a ação pela qual as pessoas apoiam umas às outras em função de um objetivo comum. É importante compreender que existe uma distinção entre as acepções sobre solidariedade. Deve-se atentar àquela que se aproxima da lógica da ajuda, uma vez que se assemelha ao "exercício elegante do poder", jamais identificado como poder, mas cativado pela ilusão de liberdade (GRONEMEYER, 2000). A ajuda passa a ser a antítese do direito e do universalismo. Desse modo, a ajuda é calculista, objetiva eliminar algum déficit e se institucionalizou e profissionalizou, semelhante à dedução da gestão estratégica. Apesar da ambiguidade que tal expressão possa conter, aqui a empregamos como a "dependência recíproca; característica dos seres [...] ligados de tal maneira que o que acontece a cada um deles repercute no outro ou nos outros" (LALANDE, 1996, p. 1051). Portanto, o significado adotado de solidariedade é aquele no qual as pessoas assumem compromissos umas com as outras sob mútua correspondência.

Na gestão dos sistemas sociais organizados, assim como de suas relações com a sociedade, as carências desses fundamentos até o presente momento são concretas. Daí a necessidade da busca de um conceito gerencial que dê conta, que se aproxime ou que vá em direção ao desejado pelo lluminismo. Assim, gestão social é um conceito que procura manter coerência com as normativas do projeto iluminista. Para tanto, recorreremos mais uma vez a Sérgio Paulo Rouanet, a fim de apoiar esse intento de aproximação, por meio do Capítulo 1, "Iluminismo ou barbárie", do livro já citado, Mal-estar na modernidade (1993), no qual o autor focaliza as categorias, por excelência, que lastrearam a llustração.

Rouanet sistematiza a redação do seu capítulo enunciando a crise da civilização moderna para, em seguida, conceituar Ilustração, assim como as categorias que a fundamentam: universalidade, individualidade e autonomia. Essas categorias servirão para Rouanet também analisar liberalismo e socialismo, e, dando continuidade e concluindo seu ensaio, descrever os tópicos a ideia iluminista e por uma civilização iluminista. Porém, neste texto, não seguiremos o roteiro originalmente traçado por Rouanet em Mal-estar da modernidade. Focalizaremos apenas o que ele denomina de elementos essenciais do projeto civilizatório da modernidade. 
Segundo Rouanet (1993, p. 9), são os seguintes os elementos essenciais do projeto civilizatório originados na modernidade: universalismo, individualidade e autonomia. Ele menciona que "esse projeto civilizatório está fazendo água por todas as juntas", pois o "universalismo está sendo sabotado por uma proliferação de particularismos - nacionais, culturais, raciais, religiosos. [...] O racismo e a xenofobia saem do esgoto [e dos armários] e ganham eleições" [aqui e alhures]. Por sua vez, a "individualidade [auxiliada pela tecnologia da informação] submerge cada vez mais no anonimato do conformismo e da sociedade de consumo". Já a "autonomia intelectual, baseada na visão secular do mundo, está sendo explodida pelo reencantamento do mundo", ${ }^{23}$ assim como a "autonomia política [é] transformada [em dependência financeira sob uma] coreografia eleitoral encenada de quatro em quatro anos" e a "autonomia econômica [empreendedorismo] ${ }^{24}$ é uma mentira sádica para os três terços do gênero humano que vive em condições de pobreza absoluta" (ROUANET, 1993, p. 10). ${ }^{25}$

Apesar das contradições anteriormente expostas por Rouanet (1993, p. 14), "o primeiro passo para a construção da ideia iluminista [desse éthos] é examinar (...) as categorias da universalidade, da individualidade e da autonomia". Assim, estas dizem respeito a:

[Universalidade] a llustração foi verdadeiramente universalista. Para ela, a ideia de que todos os homens eram iguais, independentemente de fronteiras ou culturas, estava longe de ser uma abstração retórica. O mundo, para ela, era realmente uma civitas maxima. Tratava-se de formular princípios genéricos, baseados na razão e na observação, que pudessem ajudar os seres humanos a acederem à vida civilizada. [...] Reafirmando a igualdade de todos os seres humanos diante da razão, ela transpôs para o terreno secular da luta filosófica e política a ideia religiosa de que todos são filhos de Deus e iguais diante do Criador" (ROUANET, 1993, p. 14-15).

[Individualidade], "o indivíduo passa a ser titular de direitos e não apenas de obrigações (...). O todo existe para o indivíduo e não este para o todo. Além disso, [...], a llustração os coloca em posição de exterioridade com relação ao mundo social, o que permite transformá-los em observadores e juízes de sua própria sociedade. [...]. O individualismo da llustração teve, portanto, o mérito de colocar no centro da ética o direito a felicidade e à autorrealização e o de valorizar o indivíduo descentrado, o homem que se liberta dos vínculos 'naturais' e pode situar-se na posição de formular juízos éticos e políticos a partir de princípios universais de justiça, independentemente de quaisquer lealdades locais" (ROUANET, 1993, p. 16).

[Autonomia] a "autonomia intelectual estava no cerne do projeto civilizatório da llustração. O objetivo básico era libertar a razão do preconceito, isto é, da opinião sem julgamento. [...] Donde a importância crucial da educação, única forma de imunizar o espírito humano contra as investidas do obscurantismo. [...]O ideal da autonomia intelectual [...] repousa numa petitio principii, [...]: só uma razão já livre pode travar a luta pela libertação da razão. [Por sua vez, a] autonomia política consistia para a llustração na liberdade de ação do homem no espaço público. [...] Por isso a condenação do despotismo foi a contribuição mais forte da llustração ao ideal da autonomia política. [Quanto a autonomia econômica e apesar das opiniões variarem no tocante aos meios] todos sentiam que a miséria material era um obstáculo ao progresso material e ao exercício dos direitos e obrigações civis" (ROUANET, 1993, p. 16-18, itálicos do autor e colchetes nossos).

\footnotetext{
23 "A tensão entre religião e conhecimento intelectual destaca-se com clareza sempre que o conhecimento racional, empírico, funcionou coerentemente através do desencantamento do mundo e sua transformação num mecanismo causal" (WEBER, 1971, p. 401).

24 "O mito dos milionários que começaram a vida vendendo saco de pipoca nos cruzamentos de avenidas estimula o esforço produtivo dos indivíduos, mesmo - e isso é fundamental - quando reconhecem que não enriquecerão, dispensam ou não o máximo esforço de que são capazes. Serve o mito, contudo, para sustentar a crença positiva de que o presente estágio de vida é ultrapassável, e de que o posto mais elevado na ascensão de cada um só será conhecido, e o aguarda, ao final da competição" (SANTOS, 2017, p. 95-96).

25 "Os progressos da investigação científica em todos os domínios são imagináveis. Mas onde está o progresso moral concomitante que permitiria evitar os abusos no uso da ciência (em física, em química e em biologia, por exemplo)?; O mundo inteiro se beneficiou de uma tecnologia muito eficaz. Mas a energia espiritual não acompanhou, embora pudesse ter controlado os riscos da tecnologia; estes fazem-se sentir em toda parte; Chegamos à economia que opera à escala do mundo. Mas quais são os recursos da ecologia para fazer face à destruição da natureza, também ela à escala do mundo, provocada pela industrialização? Ao longo de uma evolução complexa, a democracia impõe-se lentamente em numerosos países não europeus. Mas não se estabeleceu uma moralidade capaz de contrariar os interesses e a sede de poder dos dirigentes e dos grupos de pressão [...]: a fé na razão, no progresso e nas grandes ideologias modernas do nacionalismo, do liberalismo e do socialismo está fortemente abalada” (KÜNG, 2012, p. 704, negritos do autor).
} 
Concluindo de modo simplificado o pensamento de Rouanet (1993), evocaremos o tópico final desse Capítulo 1 da referida obra, denominado "Por uma civilização iluminista". "Bem ou mal, temos agora os contornos da ideia iluminista. Por ter se originado na história, esse paradigma não é arbitrário; e, por ser uma construção ideal, transcende a história e escapa ao relativismo" (ROUANET, 1993, p. 41). Usando o argumento weberiano do tipo ideal, ${ }^{26}$ Rouanet comenta que sua ideia iluminista é um "instrumento de investigação da realidade [porém] não deve ser confundido com ela", pois esse ens rationis deve ser utilizado para auxiliar o "pesquisador a examinar em que medida o fenômeno empírico se aproxima ou se distancia do tipo ideal". No caso específico das nossas preocupações de estudo, uma pergunta que pode ser feita, em se tratando de análise de organizações vinculadas ao setor empresarial privado, é: até que ponto a realidade gerencial da organização " $X$ " vai ao encontro dos postulados iluministas? Ou, em se tratando de decisões relacionadas ao setor público, como no caso de políticas públicas, poderemos perguntar se dada política pública atende ao paradigma iluminista. De fato, elas estão alinhadas a análise e soluções para problemas públicos, ou resultam de ideias mirabolantes, de "janelas de oportunidade", vendidas como racionais? No que concerne ao chamado terceiro setor, ou organizações denominadas de "privadas porém públicas", não governamentais, pode ser formulada a seguinte pergunta: as organizações que procuram representar os diferentes atores da sociedade civil os representam ou apenas defendem interesses individuais e/ou de grupos? O fato de uma organização declarar que tem uma finalidade social não necessariamente implica que praticam a gestão social, pois muitas delas, infelizmente, estão mais alinhadas com a lógica da gestão estratégica.

Desse modo, "podemos saber em que medida determinadas [decisões] se afastam ou se aproximam do modelo ideal, portanto ela nos proporciona um fio condutor para interrogar a realidade" (ROUANET, 1993). De acordo com Rouanet, a ideia iluminista deve ser vista como "instrumento de análise e padrão normativo. As duas funções são interdependentes. (...) A civilização iluminista [como Rouanet a denomina] é a face normativa da ideia iluminista. [...] lluminismo ou barbárie - é preciso escolher, antes que outros escolham por nós" (ROUANET, 1993, p. 45).

Não podemos, contudo, ocultar a discussão sobre o significado de modernidade sem mencionar a apreciação desenvolvida por Quijano sobre o tema quando comenta que a modernidade não é uma exclusividade europeia, eurocêntrica, na medida em que "as chamadas altas culturas (China, Índia, Egito, Grécia, Maya-Azteca, Tawantinsuyo), anteriores ao atual sistema-mundo, mostram inequivocamente sinais dessa modernidade, incluindo o racional científico, a secularização do pensamento etc." (QUIJANO, 2005, p. 212). Mais adiante, o autor complementa sua tese dizendo que "a pretensão eurocêntrica de ser exclusiva produtora e protagonista da modernidade, e de que toda modernização das populações não europeias é, portanto, uma europeização, é uma pretensão etnocentrista e a la postre provinciana" (QUIJANO, 2005, p. 213). ${ }^{27}$ Poderíamos incluir nesta discussão pensadores como Enrique Dussel, com sua original tese sobre o encobrimento da América Latina, ${ }^{28}$ e Bolívar Echeverría, sobre o éthos barroco como alternativa à modernidade capitalista. ${ }^{29}$

\footnotetext{
${ }^{26} \mathrm{O}$ "tipo ideal é um modelo abstrato que, quando usado como padrão de comparação, permite-nos observar aspectos do mundo real de uma forma mais clara e mais sistemática. [...] A falta de aderência entre tipos ideais e o mundo real não cria problema, contudo, pois não constitui objetivo dos tipos ideais descrever ou explicar o mundo. Em vez disso, fornece-nos pontos de comparação a partir dos quais podemos fazer nossas observações" (JOHNSON, 1997, p. 240).

${ }^{27}$ Aníbal Quijano justifica essa posição apontando vários exemplos fora do mundo europeu ocidental que justificam que a modernidade racional-científica, entre outros avanços, não tinha essa exclusividade eurocêntrica: “Na verdade, a estas alturas da pesquisa histórica, seria quase ridículo atribuir às culturas não europeias uma mentalidade mítico-mágica como traço definidor, por exemplo, em oposição à racionalidade e à ciência como característica de Europa, pois aparte dos possíveis ou mais bem conjecturados conteúdos simbólicos, as cidades, os templos e palácios, as pirâmides, ou cidades monumentais, seja Machu Picchu ou Borobudur, as irrigações, as grandes vias de transporte, as tecnologias metalíferas, agropecuárias, as matemáticas, os calendários, a escritura, a filosofia, as armas e as guerras, dão conta do desenvolvimento científico e tecnológico em cada uma de tais altas culturas, desde muito antes da formação da Europa como nova identidade" (QUIJANO, 2000, p. 213).

28 "A modernidade originou-se nas cidades europeias medievais, livres, centros de enorme criatividade. Mas 'nasceu' quando a Europa pôde se confrontar com o seu 'Outro' e controlá-lo, vencê-lo, violentá-lo: quando pôde se definir como um 'ego' descobridor, conquistador, colonizador da Alteridade constitutiva da própria Modernidade. De qualquer maneira, esse Outro não foi 'descoberto' como Outro, mas foi 'en-coberto' como o 'si mesmo' que a Europa já era desde sempre" (DUSSEL, 1993, p. 8).

29 "O éthos barroco, como os outros ethe modernos, consiste em uma estratégia para tornar 'visível' algo que basicamente não é: a atualização capitalista das possibilidades abertas pela modernidade, [...] ser hoje barroco significa ameaçar, julgar e parodiar a economia burguesa, baseada na tacanha administração dos bens, em seu centro e fundamento" (ECHEVERRÍA, 2000, p. 15-16).
} 


\section{CONSIDERAÇÕES FINAIS: GESTÃO SOCIAL OU GESTÃO ESTRATÉGICA?}

É preciso escolher, antes que cálculos inconsequentes eliminem as relações entre homens e mulheres de diferentes raças, entre a humanidade e a natureza ou entre o humanidade e as organizações.

O texto ora em pauta não tem a pretensão de ser conclusivo e definidor exclusivo do significado de gestão social. Como observamos nos preâmbulos deste artigo, o conceito de gestão social está na agenda da academia brasileira, porém não é unânime sua compreensão, como também é desconhecido por grande parte da mesma academia, quiçá no contexto internacional. Há também aqueles que, quando o empregam, o confundem com gestão de práticas assistencialistas de ajuda, gestão de políticas públicas compensatórias e gestão de organizações do terceiro setor, além de outros que o consideram utópico, sem veracidade. Na realidade, há uma forma gerencial dominante, hegemônica, inclusive atuando nos processos de ensino-aprendizagem: a gestão estratégica, configuração gerencial que tem como postulado o curto prazo, a redução, o lucro, valores objetivados por meio de categorias como eficiência, produtividade e quejandos. Sob o éthos do mercado, do valor de troca, a eficiência, como a produtividade, procura ser alcançada pela promoção de relações sociais estratificadas, hierarquizadas, mantenedoras da relação senhor-escravo, substanciada pelo processo da reificação, da alienação. ${ }^{30}$

Por outro lado, grande parte da sociedade, aqui e alhures, ainda carece do básico para sua subsistência: alimentação, moradia, educação, saúde, segurança, transporte etc., portanto é despossuída de bem-estar geral, de justiça social, de proteção social. Qual parâmetro poderia minimizar tais carências geradas pelas desigualdades sociais, raciais e de gênero, entre outras?

Se considerarmos que o suprimento dessas carências é exigido desde a modernidade, o parâmetro seria aquele que atendesse às privações que ainda afligem grande parte da humanidade, bem como o que promovesse a tríade liberdade, igualdade e solidariedade. Se desejarmos ser consequentes com o ano celebrador da modernidade, 1789, a prática republicana deveria ser o norte orientador das ações gerenciais, um caminho de possibilidades baseado numa gestão compartilhada com a sociedade, com a totalidade, em detrimento daquela orientação voltada para o mercado, isto é, para a parcialidade. Para esse enclave, o mercado, lastreado pelo valor de troca, já vem atuando de maneira dominante, com a gestão estratégica orientadora da exclusão do outro. O que precisamos é de ideologias e práticas gerenciais nas quais o(a) outro(a) seja incluído(a); uma inclusão exercida sob esferas públicas, em que seus participantes devem atuar como cidadãos ativos, deliberativos, ocupando-se da res publica. Portanto, atuar em qualquer setor da sociedade de modo republicano é agir em função de todos(as), do bem-estar geral.

Desse modo, o intento deste texto, repetimos, foi reprisar um conceito - gestão social - que, desde o início dos anos 1990, é contraposto ao de gestão estratégica. Assim, trata-se de uma dissidência, uma perspectiva heterodoxa frente ao mainstream; de um conceito de resistência não como fim ou meta da política, e sim como seu começo e possibilidade, como tensão entre a sujeitificação e a subjetividade ativa, ${ }^{31}$ na relação entre opressão e resistência, sem apelação ao sentido de agenciamento máximo do sujeito moderno.

Procurou-se enfatizar que o conceito de gestão social deve ser submetido aos cânones da modernidade. Ou seja, o conceito de uma gestão compartilhada, dialógica, deve recorrer aos parâmetros do lluminismo para fazer frente à contemporaneidade tecnoburocrática. Talvez possamos esclarecer esse intento recorrendo a Benjamin no seu escrito Sobre o conceito da história, quando, na sétima tese, diz que a tarefa é "escovar a história a contrapelo" (BENJAMIN, 2012, p. 245). Portanto, devemos atuar em direção contrária ao domínio da racionalidade instrumental, ao revés do domínio da gestão estratégica, por meio de outro conceito de gestão que busca a democratização das relações sociais no interior das organizações e desta com a sociedade.

Assim, tendo como subsídio a tese benjaminiana, diríamos que atuar a contrapelo da gestão estratégica, do pensamento organizacional monológico, por meio ou com base na gestão social, é dizer que o processo gerencial funcionalista é o processo exercido pelos dominantes. Em direção contrária a essa gestão autoritária, tecnoburocrática, pretendemos aquele éthos de uma ação gerencial compartilhada no processo de produção de bens e/ou serviços, procurando também, nesse pentear em

\footnotetext{
${ }^{30} \mathrm{Na}$ atualidade, procuram alcunhar o trabalhador de "colaborador", "empreendedor" etc.

31 "A subjetividade que resiste com frequência expressa-se infrapoliticamente, em vez de em uma política do público, a qual se situa facilmente na contestação pública. Legitimidade, autoridade, voz, sentido e visibilidade são negadas à subjetividade oposicionista. A infrapolítica marca a volta para o dentro, em uma política de resistência, rumo à libertação. Ela mostra o potencial que as comunidades dos/as oprimidos/ as têm, entre si, de constituir significados que recusam os significados e a organização social, estruturados pelo poder. Em nossas existências colonizadas, racialmente gendradas e oprimidas, somos também diferentes daquilo que o hegemônico nos torna. Esta é uma vitória infrapolítica” (LUGONES, 2014, p. 940).
} 
direção oposta ao caimento natural do pelo, apontar as contradições inerentes a qualquer tipo de funcionalidade, buscando promover processos participativos que impliquem melhor organização política da sociedade.

A questão não é "jogar a água com a criança”, e sim que as práticas funcionais exercidas com base na racionalidade instrumental sejam submetidas a uma racionalidade que promova a intersubjetividade dos sujeitos sociais, transformando-os em sujeito coletivo. A racionalidade instrumental deve ser submetida ao crivo daqueles a ela concernentes, horizontalmente legitimada, e não imposta de cima para baixo. Portanto, a gestão que propomos não é um mero processo participativo no qual os envolvidos são somente convocados e não decidem. $O$ processo que propomos sob a perspectiva da gestão social é, ao mesmo tempo, dialógico e deliberativo. Dialógico na medida em que todos possam refletir e expor seus argumentos e deliberativo na medida em que a tomada de decisão é democrática. É também dialética na medida em que "atribui grande importância à busca e à eliminação de contradições, processo [...] desenvolvido a partir do diálogo, ou seja, um processo de discussão entre uma série de interlocutores" (ALBERT, 1969, p. 61). A gestão social, ao se colocar em oposição à gestão estratégica, facilita o entendimento de suas contradições porque ilumina criticamente, destacando suas fraquezas e desenvolvendo perspectivas para seu melhoramento. Se discutirmos a gestão estratégica pelos seus cânones, poderemos apenas propor reformas, paliativos na sua maneira de atuar, mas não mudanças na realidade histórico-social.

Assim, a gestão social pretende, desde seu éthos fundamentado no lluminismo, identificar as contradições impostas pela gestão estratégica e contribuir para a emancipação do ser social, do seu autogoverno por meio de arranjos institucionais, de espaços públicos, que promovam o entendimento intersubjetivo dos seres sociais - espaços nos quais as liberdades individuais sejam subsumidas à liberdade social, uma vez que o "indivíduo não pode ser livre se nem todos forem livres, e nem todos podem ser livres se nem todos forem livres no que é comum" (HABERMAS, 2015, p. 124). Reflete-se, dessa forma, que é preciso reafirmar e avançar na compreensão de e sobre a gestão social no que diz respeito ao seu sentido originário epistemológico e axiológico decolonial. A incorporação dos debates sobre desigualdades e diversidades (raça, gênero, classe social, orientação sexual, pessoas com deficiências entre outras) é cada vez mais urgente, e nos parece que, no âmbito das ciências administrativas, tem mais aderência a lógica da gestão social do que a da gestão estratégica.

Em síntese, o conceito de gestão aqui enfatizado não deseja ser um conceito de práticas condutoras de comportamentos, como o faz a gestão estratégica. O que pretendemos é um conceito de gestão cujos resultados e práticas tenham significado às demandas da sociedade, do bem comum, por meio de arranjos coletivos internos às organizações, assim como destas com a sociedade. Para isso, é preciso apreender com a "memória coletiva" 32 articulada com a aposta decolonial para entender como é o viver de luz e liberdade frente às trevas, não impondo nem moldando racionalidades fundadas em binarismos dicotômicos, classificatórios, hierárquicos (WALSH, 2013).

A gestão social, portanto, pretende ser coerente com os pressupostos da modernidade, notadamente aqueles referentes à res publica, o que exige que tal proposta gerencial também seja coerente, no caso brasileiro, com a Constituição de 1988, cuja prática, infelizmente, ainda não guarda sentido com seus preceitos fundamentais, uma vez que o exercício da cidadania não ocorre pela participação direta no governo de suas comunidades políticas. Interagindo com isso, há ainda o fato de os poderes Executivo, Legislativo e Judiciário não atuarem de modo razoável à Constituição. Acompanhando a tese do pensador Dolf Sternberger (2001), falta-nos agir de forma patriótica aos preceitos constitucionais brasileiros.

Apesar das "feridas do esclarecimento", a Administração, assim como outras ciências sociais aplicadas, tem contribuído para essas lesões, pois "não há nenhum remédio a não ser o do próprio Esclarecimento radicalizado" (HABERMAS, 2015, p. 316).

Enquanto concluímos este texto, o Brasil, desde 2016, vem passando por um processo no qual os preceitos constitucionais de 1988 parecem não fazer mais sentido. Não apontamos nesse caso apenas a corrupção, que solapa todos os setores da sociedade, mas também até que ponto tais preceitos, relacionados a uma ativa participação cidadã, serão objeto de práticas num futuro não muito distante ${ }^{33}$. Assim, discutir possibilidades de um processo gerencial democrático, uma gestão social, não seria ingenuidade?

\footnotetext{
32 "A memoria coletiva tem sido - e todavia é - um espaço entre otros nos qual se entrelaça na mesma prática o pedagógico e o decolonial [...] A memoria coletiva é a reafirmação do que a tradição nos ensina, do que nossa ancestralidade ensina [...] Disse uma vez o professor e avô do movimento afroequatoriano, Juan García Salazar: 'Justamente é memória coletiva porque está em todo o coletivo [...] é um saber coletivizado; é á consolidação, o que nos permite continuar'” (WALSH e GARCÍA apud WALSH, 2013, p. 26 - tradução livre)

${ }^{33} \mathrm{O}$ que está ocorrendo no Brasil é uma ruptura constitucional na medida em que "[a] primeira consequência é que passamos da constituição simbólica para a degradação da Constituição. Por um lado, o cinismo das elites prevalece. Por outro lado, aprofunda-se a apatia do público. [...] Neste contexto, destaca-se o desmonte das instituições do Estado social, já muito precárias. Esse desmonte continuará para aumentar a já elevada desigualdade e exclusão social" (NEVES, 2017, p. 82).
} 


\section{REFERÊNCIAS}

AGUIAR-BARBOSA, A. P.; CHIM-MIKI, A. F. Evolução do conceito de gestão social (1990-2018): uma análise de co-palavras. Cadernos de Gestão Pública e Cidadania, São Paulo, v. 25, n. 80, p. 1-22, e-80525, 2020.

ALBERT, H. Tratado da razão crítica. Rio de Janeiro: Tempo Brasileiro, 1969.

ANDERSON, P. As origens da pós-modernidade. Rio de Janeiro: Zahar, 1999.

ARAÚJO, E. T. (In)Consistências da gestão social e seus processos de formação: um campo em construção. 2012. Tese (Doutorado em Serviço Social) - Pontifícia Universidade Católica de São Paulo, Programa de Estudos Pós-graduados em Serviço Social, São Paulo, 2012.

BAUMAN, Z.; BORDONI, C. Estado de crise. Rio de Janeiro: Zahar, 2016.

BENJAMIN, W. Magia e técnica, arte e política: ensaios sobre literatura e história da cultura. 8. ed. rev. São Paulo: Brasiliense, 2012. (Obras escolhidas, v. 1.).

BOTTOMORE, T.; OUTHWAITE, W. (Orgs.). Dicionário do pensamento social do século XX. Rio de Janeiro: Zahar, 1996.

BRASIL. [Constituição (1988)]. Constituição da República Federativa do Brasil. Brasília, DF: Senado Federal, Coordenação de Edições Técnicas, 2016. Disponível em: <www2.senado.leg.br>. Acesso em: 04 ago. 2017.

CANÇADO, A. C. Fundamentos teóricos da gestão social. 2011. Tese (Doutorado em Administração) - Universidade Federal de Lavras, Minas Gerais, 2011.

COELHO, F.; MENON, I. O. Gestão social como campo do saber no Brasil: uma investigação de sua produção científica pela modelagem de redes sociais. Cadernos Gestão Pública e Cidadania, São Paulo, v. 24, n. 70, e-79851, 2019.

DUSSEL, E. 1492: o encobrimento do outro - a origem do mito da modernidade - Conferências de Frankfurt. Petrópolis: Vozes, 1993.

ECHEVERRÍA, B. La modernidad de lo barroco. Cidade do México: Era, 2000.

GIOVANNI, G.; NOGUEIRA, M. A. (Orgs.). Dicionário de políticas públicas. 2. ed. São Paulo: Unesp; Fundap, 2015.

GRONEMEYER, M. Ajuda. In: SACHS, W. (Org.) Dicionário do desenvolvimento: guia para o conhecimento como poder. Petrópolis: Vozes, 2000. p. 18-39.

GUALEJAC, V. A gestão como doença social: ideolologia, poder gerencialista e fragmentação social. Aparecida: Idéias \& Letras, 2007.

HABERMAS, J. La modernidad: un proyecto incompleto. In: HABERMAS, J. et al. La posmodernidad. Barcelona: Kairós, 1985.

HABERMAS, J. Teoría de la acción comunicativa, v. 1 e v. 2. Madrid: Taurus, 1987.

HABERMAS, J. La soberania popular como procedimiento. Cuadernos Políticos, Cidade do México, n. 57, p. 53-69, maio/ago. 1989.

HABERMAS, J. A nova obscuridade. São Paulo: Unesp, 2015.
HEGEL, G. W. F. Fenomenologia do espírito. 6. ed. Petrópolis/Bragança Paulista: Vozes/Ed. Universitária São Francisco, 2011.

HOBSBAWM, E. A era das revoluções (1789-1848). 18. ed. São Paulo: Paz e Terra, 2004.

ISRAEL, J. A revolução das luzes: o lluminismo Radical e as origens intelectuais da democracia moderna. São Paulo: Edipro, 2013.

JAMENSON, F. Modernidade singular. Rio de Janeiro: Civilização Brasileira, 2005.

JAPIASSU, H.; MARCONDES, D. Dicionário básico de filosofia. Rio de Janeiro: Zahar, 1990.

JASPERS, K. Razão e anti-razão em nosso tempo. Rio de Janeiro: Iseb/MEC, 1958.

JOHNSON, A. G. Dicionário de sociologia: guia prático de linguagem sociológica. Rio de Janeiro: Zahar, 1997.

KANT, I. Textos seletos. 4. ed. Petrópolis: Vozes, 2008.

KÜNG, H. O cristianismo. Lisboa: Temas e Debates/Círculo Leitores, 2012.

LALANDE, A. Vocabulário técnico e crítico da filosofia. São Paulo: Martins Fontes, 1996.

LUGONES, M. Rumo a um feminismo descolonial.Tradução: Juliana Watson e Tatiana Nascimento. Estudos Feministas, Florianópolis, n. 22, v. 3, p. 935-952, set./dez. 2014.

LYOTARD, J.-F. A condição pós-moderna. Rio de Janeiro: José Olympio, 2006.

MARSAIS, C. C. du. Filosofia clandestina: cinco tratados franceses do século XVIII. São Paulo: Martins Fontes, 2008.

MENDONÇA, C. E. R. de. Trotsky e a revolução permanente: história de um conceito chave. Rio de Janeiro: Garamond, 2014.

MINOIS, G. História do ateísmo: os descrentes do mundo ocidental, das origens aos nossos dias. São Paulo: Unesp, 2014.

MATTEUCCI, N. Bem Público. In: BOBBIO, N.; MATTEUCCI, N.; PASQUINO, G. Dicionário de Política. 13 ed. (reimpressão). Brasília, DF: UnB, 2010, p. 106-107.

NEVES, M. Corrupção, exclusão e exceção - vai acabar dando revolução. Inteligência, n. 77, ano XX, abr./jun. 2017. Disponível em: <insightinteligencia.com.br>. Acesso em: 05 ago. 2017.

PAGDEN, A. La ilustración y sus enemigos: dos ensayos sobre los orígenes de la modernidad. Barcelona: Ediciones Península, 2002.

PAYNE, M. (Comp.). Dicionário de teoría crítica y estudios culturales. Buenos Aires: Paidós, 2002.

QUIJANO, A. Colonialidade do poder, eurocentrismo e América Latina. In: LANDER, E. (Org.). La colonialidad del saber: eurocentrismo y ciencias sociales - perspectivas latinoamericanas. Buenos Aires: CLACSO, 2005.

ROUANET, S. P. Do pós-moderno ao neomoderno. Revista Tempo Brasileiro, Rio de Janeiro, v. 1, n. 1, p. 86-97, 1962. 
ROUANET, S. P. Mal-estar na modernidade: ensaios. São Paulo: Companhia das Letras, 1993.

SANTOS, W. G. dos. A democracia impedida: o Brasil no século XXI. Rio de Janeiro: FGV, 2017.

SENNETT, R. A corrosão do caráter: consequências pessoais do trabalho no novo capitalismo. Rio de Janeiro: Record, 1999.

SILVA, L. P. da. Metanarrativas e jogos de linguagem: Lyotard e a crítica da modernidade, 2012. Disponível em: <www.seminariodehistoria. ufop.br>. Acesso em: 03 ago. 2017.

STERNBERGER, D. Patriotismo constitucional. Bogotá: Universidad Externado de Colombia, 2001.

SVAMPA, M. Debates latino-americanos. Buenos Aires: Edhasa, 2016.
TENÓRIO, F. G. Gestão social: uma perspectiva conceitual. Revista de Administração Pública, Rio de Janeiro, v. 32, n. 5, p. 7-23, set./ out., 1998.

TENÓRIO, F.G. Tem Razão a Administração?. Rio Grande do Sul: Unijuí, 2002.

TOURAINE, A. Crítica da modernidade. Petrópolis: Vozes, 1994.

WANDERLEY, L. E. Enigmas do social. In: CASTEL, R.; WANDERLEY, L. E.; BELFIORE-WANDERLEY, M. Desigualdade e a questão social. 3 ed. rev. amp. São Paulo: Educ, 2008. p. 167-226.

WALSH, C. Lo pedagógico y lo decolonial: entrejiendo caminos. In: WALSH, C. (Ed.). Pedagogías decoloniales: prácticas insurgentes de resistir, (re) existir y (re)vivir. Quito: Abya Yala, 2013. Série Pensamiento Decolonial.

WEBER, M. Ensaios de sociologia. Rio de Janeiro: Zahar, 1971.

Fernando Guilherme Tenório

ORCID: https://orcid.org/0000-0002-4373-6558

Professor colaborador na Escola Brasileira de Administração Pública e de Empresas da Fundação Getulio Vargas (FGV EBAPE), na Universidade Federal do Tocantins (UFT) e na Universidade Regional do Noroeste do Estado do Rio Grande do Sul (UNIJUÍ); Professor visitante na Universidade Andina Simón Bolívar (UASB), e na Escuela Politécnica Nacional, Quito - Equador. E-mail: fernandoguilhermet@gmail.com

Edgilson Tavares de Araújo

ORCID: https://orcid.org/0000-0002-2145-8796

Doutor em Serviço Social pela Pontifícia Universidade Católica de São Paulo e Universidade Católica Portuguesa (Lisboa); Pós-doutorado em Desenvolvimento, Sociedade e Cooperação Internacional pelo Centro de Estudos Avançados Multidisciplinares na Universidade de Brasília (CEAM/UnB); Bolsista de Produtividade em Desenvolvimento Tecnológico e Extensão Inovadora do CNPq (DT - nível 2); Professor da Escola de Administração da Universidade Federal da Bahia (UFBA); Professor permanente do Mestrado Profissional em Gestão de Políticas Públicas e Segurança Social da Universidade Federal do Recôncavo da Bahia (PPGPPSS/UFRB); Presidente da Associação Nacional de Ensino e Pesquisa do Campo de Públicas (ANEPCP); Membro da Rede de Pesquisadores em Gestão Social (RGS). E-mail: edgilson@gmail.com 